\title{
석회화음영을 동반한 거대한 폐종괴
}

한양대학교 의 과대학 내과학교실

\section{임병성·신동호·박성수・이정희}

\section{증 례}

31 세의 남자환자가 약 5 개월 전 우측에 유방이 커져서 개인의원에서 훙부 $\mathrm{X}$-선 검사 및 단층촬영과 컴퓨터단 층 촬영을 실시하여 좌상부 $11.5 \times 10 \mathrm{~cm}$ 크기의 원형의 종괴가 발견되었고 수술을 권유받았으나 특별한 증상이 없어 그냥 지내다가 수술 위해 입원하였다.

열이나 체중감소도 없었고 담배는 하루 1갑 이상씩 5 년동안 홉연하였다. 직업은 농촌에서 농작물을 재배하 는 것 이외에는 asbestos에 노출된 특별한 주위환경은 없었다. 입원 당시 이학적 소견에서 특이한 이상소견은 관찰되지 않았고 건강해 보였으며 의식은 명료하였다.

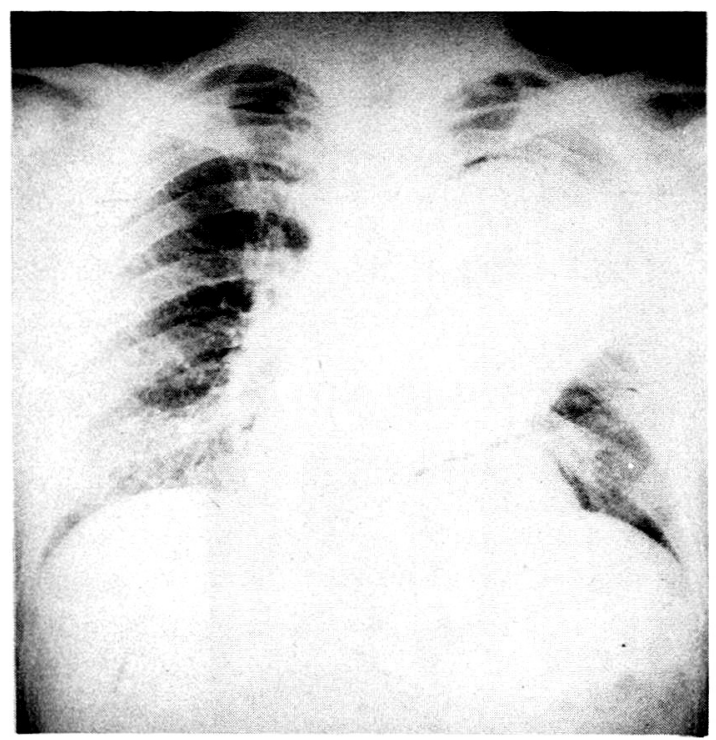

Fig. 1. At the chest P-A view, about $11.5 \times 10 \mathrm{~cm}$ sized relatively well marginated homogenous increased density mass is noted in the left upper and middle lung.
체온은 $36.2^{\circ} \mathrm{C}$, 맥박 71 회/분, 호홉수 20 회/분, 혈압은 $130 / 70 \mathrm{mmHg}$ 였다. 결막은 창백하지 않았고 공막도 황 달기가 없었으며 경부경정맥 노장은 없었다. 경부에 특 별한 종괴도 촉진되지 않았다. 홍부청진에서 특별한 수 포음이나 천명은 없었고 좌측 두번째 늑간에서 심장음이 전도가 잘 되었고 호흡음이 약간 감소된 것 이외에는 특 이한 소견이 없었다. 간장이나 비장은 촉지되지 않았고 곤봉상의 수지나 사지부종도 없었다. 단순 홍부 X-선 검사에서 좌상부 전엽에 $11.5 \times 10 \mathrm{~cm}$ 크기의 경계가 명 확한 원형의 종괴가 관찰되었다. 그외의 특별한 폐실질 내 음영이나 석회화음영은 관찰되지 않았다(Fig. 1 \& 2). 홍부 컴퓨터 단층찰영 소견상 석회화음영과 경계가 불확실한 low density 부위를 가진 종괴가 좌상부엽의 전엽에서 관찰되었다(Fig. 3). ECG는 정상소견이었고

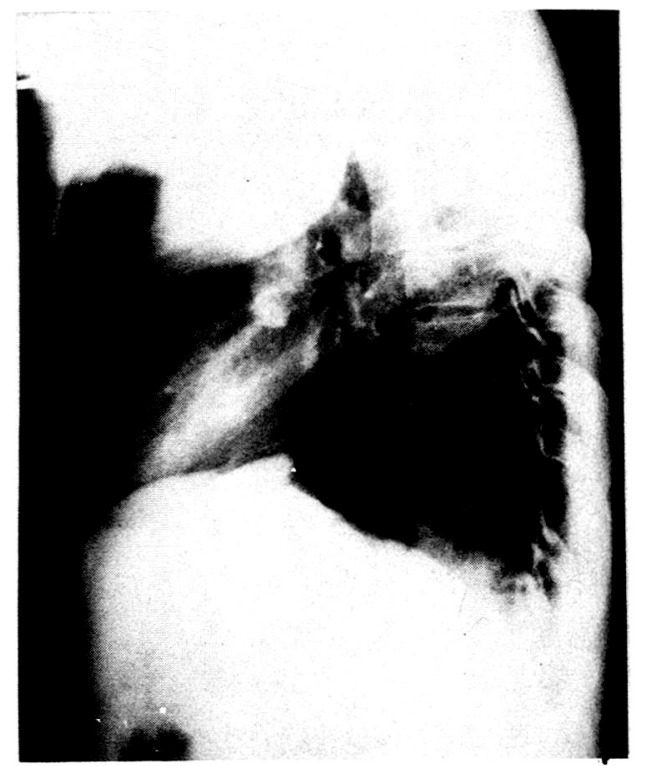

Fig. 2. At the left lateral view, the mass is located in the anterior segment of the left upper lobe. 
혈액검사는 $\mathrm{Hb} 15.1 \mathrm{~g} / \mathrm{dl}, \mathrm{Hct} 46 \%$, WBC $6800 / \mathrm{mm}^{3}$ 였다. 전해질, 신기능, 폐기능검사, 복부초을파 검사 등 은 정상범위였다. 간기능검사상 ALT는 62 units, AST 는 41 units였다. 혈청 CEA치는 $3.5 \mu \mathrm{g} / 1$ 였다. 연속 3 회 객담항산성 도말검사에서 음성이었고, 객담세포 진 단학상 암세포도 관찰되지 않았다. 경피적 폐침생검사 상 혈액의 배설물을 보였으며, 세포진단학 검사상 class I 이었고, 악성세포는 발견되지 않았다. 홍부외과로 전 과되어 전신 마취하에 좌상엽절제술 및 좌측 두번째, 세

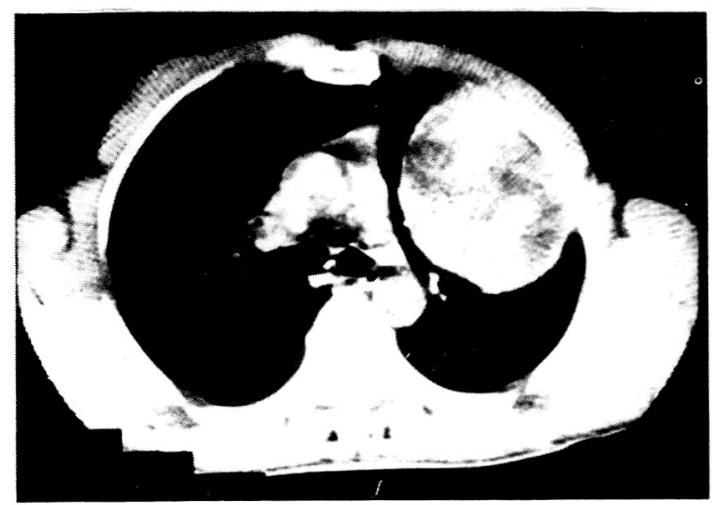

Fig. 3. At the chest C-T scan, about $10 \times 5 \mathrm{~cm}$ sized inhomogenous soft tissue density mass containing calcification and ill-defined low density area is noted in the left upper lobe, anterior segment territory.
번째 늑골을 부분적으로 절제하였다. 회백색의 $11 \times 8 \times$ $4 \mathrm{~cm}$ 의 종괴가 좌상엽에 위치하고 있었고, 2,3 번째 늑 골이 전방에 위치하고 있었다. 조직병리검사에서 현미 경 소견상 종양세포들은 하방의 폐실질을 침윤하고, 주 위 종격동 연부조직으로 증식하고 있었다. 종양을 구성 하고 있는 세포들은 방추상 또는 난원형으로 군데군데 호산성의 교원 섬유성 간질이 소량으로 관찰되었다. 종 양세포들은 소량의 호산성 세포질을 가지고 치밀하게 짜 여져 있었고, 인접한 종양세포들과 뚜렷한 경계를 이루 고 있지 않았다. 종양세포의 핵은 농염되고 간혹 핵소체 가 관찰되었다. 소수의 핵분열이 종양세포에 나타났고 상피성종양 세포들은 관찰되지 않았다(Fig. 4).

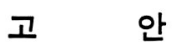

31 세의 젊은 남자의 경계가 명확하고 균일한 음영의 종괴에 대한 폐내성(intrapulmonary lesion)인지 폐외 성 (extrapulmonry lesion) 인지 감별진단이 필요하다. 폐외성의 특징으로는 훙벽 등 접하고 있는 부분이 기저 부분을 이루고 경계가 되는 각이 둔각으로 나타나며 폐 외에 접하고 있는 구조의 경계되는 음영이 관찰되지 않 는다.

본 증례에서는 종괴의 중심이 폐내에 위치하고 있고 각이 예각을 이루고 있는 것으로 보아 폐내에서 발생한

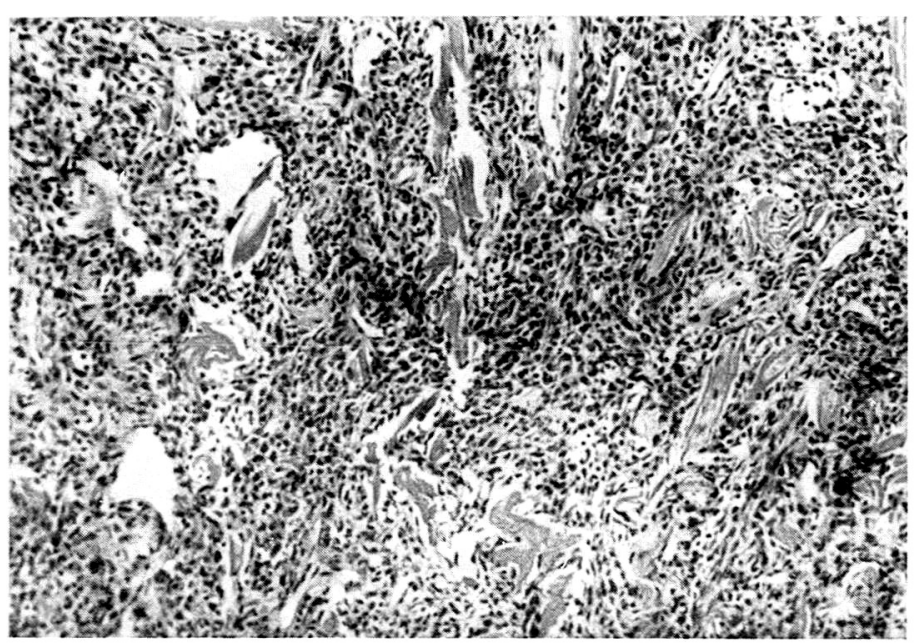

Fig. 4. The tumor is composed of compact sheets of spindled to oval cells. Abundant eosinophilic hyalinized fibrous materials are interspersed between tumor cells $(\mathrm{H} \& \mathrm{E}, \times 100)$. 
Table 1. Solitary Pulmonary Nodule or Mass

I. Neoplastic

\section{A. Malignant}

1. Primary carcinoma of the lung

2. Metestasis (e.g., kidney, colon, ovary, testis, Wilm's tumor, sarcoma)

3. Lymphoma

4. Primary sarcoma of lung

5. Plasmacytoma (primary or secondary)

B. Benign

1. Hamartoma

2. Chondroma

3. Arteriovenous malformation

4. Lipoma (usually pleural lesion)

5. Amyloidosis

6. Leiomyoma

7. Hemangioma

8. Intrapulmonary lymph node

9. Endometrioma

10. Fibroma

11. Neural tumor (schwannoma and neurofibroma)

12. Paraganglioma (chemodectoma)

13. Inflammatory pseudotumor (fibroxanthoma, histiocytoma, plasma cell granuloma, sclerosing hemangioma)

II. Inflammatory

A. Granuloma

1. Tuberculosis

2. Histoplasmosis

3. Coccidioidomycosis

4. Cryptococcosis (torulosis)

5. Nocardiosis

6. Talc

7. Dirofilaria immitis (dog heartworm)

8. Gumma

9. Atypical measles infection

10. Sarcoidosis

11. Q fever

B. Abscess

C. Hydatid cyst (fluid-filled)

D. Bronchiectatic cyst (fluid-filled)

E. Fungus ball

F. Organizing pneumonia (atypical measles pneumonia, cytomegalic inclusion virus)

G. Inflammatory pseudotumor

H. Bronchocele and mucoid impaction

III. Vascular
A. Infarct (organizing)
B. Pulmonary vein varix or anomaly
C. Rheumatoid nodule
D. Wegener's

IV. Developmental
A. Bronchogenic cyst (fluid-filled)
B. Pulmonary sequestration

V. Inhalation
A. Silicosis (conglomerate mass)
B. Mucoid impaction (allergic aspergillosis)
C. Paraffinoma (lipoid granuloma)
D. Aspirated foreign body

VI. Other
A. Hematoma
B. Extramedullary hematopoiesis
C. Emphysematous bulla (fluid-filled)
D. Thrombolytic therapy
E. Mimicking densities

1. Fluid in interlobar fissure

2. Mediastinal mass

3. Pleural mass (mesothelioma)

4. Chest wall density (nipple, rib lesion, skin tumor)

5. Artifacts

Table 2. Radiographic Findings in 58 Localized Fibrous Tumors of the Pleura

\begin{tabular}{lrc}
\hline \hline \multicolumn{1}{c}{ Finding } & No. (\% of Total) \\
\hline Characteristics of the mass & & \\
Sharply circumscribed borders & 54 & $(93)$ \\
III-defined borders & 2 & $(3)$ \\
Borders obscured by effusion & 2 & $(3)$ \\
Round contour & 46 & $(79)$ \\
Lobulated contour & 9 & $(16)$ \\
Size of mass (cm) at presentation & & \\
$0-5$ & 20 & $(34)$ \\
$6-10$ & 25 & $(43)$ \\
11-15 & 4 & $(7)$ \\
$>15$ & 6 & $(10)$ \\
Obscured by effusion & 3 & $(5)$ \\
Recurrence & & \\
Localized mass & 3 & $(5)$ \\
Diffuse disease & 2 & $(3)$ \\
Pleura & & \\
Ipsilateral effusion & 10 & $(17)$ \\
Plaque & 1 & $(2)$ \\
\hline
\end{tabular}


것으로 생각된다. 종괴는 형태적으로 air bronchogram 이 전혀 보이지 않고 있고 폐야 주변부에 위치하고 있 고, 종괴부위에 다른 음영는 관찰되지 않았다. 감별진단 하여야 할 질환은 Table 1 에서와 같다 ${ }^{11}$. 이 많은 질환 중에 입원 당시 발열이나 백혈구 증다증 등 염증성 증상 이 없는점으로 염증성 종양 보다는 양성 혹은 악성종양 이 의심된다. 크기에 있어서 거대한 폐종괴인 것으로 악 성종양일 가능성이 많다. 경계가 명확한 것으로 보아서 는 혈관조적이나 평활근 등 결체조직에서 발생되는 종양 도 의심할 수 있다. 또한 석회화음영이 관찰되는 점으로 과오종, 혈관종, 기형종도 감별진단을 해야 한다. 종괴 의 경계가 비교적 뚜렷하고, 석회화 음영을 관찰할 수 있었고, 그래서 수술을 시행하였다. 진단은 홍막의 “국 한성 악성 섬유성 중피세포종(局限性 惡性 纖維性 中皮 細胞 腫, localized malignant fibrous mesothelioma)"로 확진하였다.

조직학적으로 한외구조 및 면역조직 화학적으로 상피 세포의 분화는 발견되지 않는 점으로 국한성 중피세포종 대신에 국한성 섬유성 중피세포종으로 명 경함이 좋다.

국한성 섬유성 증피세포종은 원인은 잘 모르고 약 과 반수에서 본 중례와 같이 특이한 증상 없이 훙부 X-선 검사상 우연히 발견된다 ${ }^{2)}$. 국한성 섬유성 증피세포종은 양성과 악성 형태로 존재한다. England등ㄱㅇㅢ 보고에 의하면, Table 2 에서와 같이 58 예의 국한성 섬유성 증 피세포종의 홍부 X-선 소견상 종양의 특징은 뚜렷한 경 계면을 갖는 소견이 $93 \%$ 로 가장 많았고 둥근 외형소견 이 $79 \%$, 소엽 외형소견이 $16 \%$ 순이었다. 본 예에서는 둥근 외형소견을 나타냈었다. 종양의 크기는 $6 \sim 10 \mathrm{~cm}$ 가 $43 \%$ 로 가장 많았고 $0 \sim 5 \mathrm{~cm}$ 가 $34 \%, 15 \mathrm{~cm}$ 이상이
$10 \%, 11 \sim 15 \mathrm{~cm}$ 가 $7 \%$ 순이었다. 본 예에서는 $11.5 \times 10$ $\mathrm{cm}$ 이었다. 골관절병 증 (骨關節病症)은 섬유성 중피세포 종 환자의 $35 \%$ 에서 나타나나, 악성 섬유성 중피세포종 에서는 드물게 나타난다4). 국한성 향막 섬유성 중피세 포종의 $80 \%$ 는 장측흥막에서 $20 \%$ 는 벽측훙막에서 기원 한다2). 본 예에서도 장측훙막에서 기원하였다. 종양경 (pedicle)의 유무로 악성과 양성을 감별할 수 있다 ${ }^{2)}$. 악 성시 종양경은 발견할 수 없고, 본 증례에서도 종양경은 발견할 수 없다. 저혈당증은 양성 섬유성 중피세포종 환 자의 $4 \%$ 에서 나타난다 ${ }^{2}$. 흥막의 국한성 섬유성 중피세 포종들은 때때로 석회화한닥.

\section{REFERENCES}

1) Reed, JC: Chest Radiology, Plain film patterns and differential diagnosis. 2nd Ed., p256 Chicago London, Year Book Medical Publishers. INC, 1987

2) Briselli M, Mark EJ, Dickersin GR: Solitary fibrous tumors of the pleura: eight new cases and a review of 360 cases. Cancer 47: 2678, 1981

3) England DM, Hochholzer L, McCarthy MJ: Localized benign and malignant fibrous tumors of the pleura: a clinicopathologic review of 223 cases. Am J Surg Pathol 13: 640, 1989

4) Wierman WH, Clagett OT, McDonald JR: Articular manifestations in pulmonary diseases.: an analysis of their occurrence in 1,024 cases in which pulmonary resection was performed. JAMA 155: 1459, 1963

5) Hutchinson $\mathrm{WB}$, Friedenberg $\mathrm{MJ}$ : Intrathoracic mesothelioma. Radiology 80: 937, 1963 


\section{A Large Well Marginated Round Mass Containing Calcification}

Byung Sung Lim. M.D., Dong Ho Shin, M.D.. Sung Soo Park, M.D. and Jung Hee Lee, M.D.

Department of Internal Medicine, College of Medicine, Hanyang University, Seoul, Korea

A 31-year-old male has a $11.5 \times 10 \mathrm{~cm}$ sized relatively well marginated round mass containing peripheral calcification in left upper lung field on chest roentgenograms and computed tomogram. There are no presenting symptoms including weight loss, and occupational exposures. Definitive diagnosis must differentiate from the variety of diseases whether malignancy or benign, extrapulmonary or intrapulmonary.

This report described one case of malignant localized fibrous mesothelioma histologically. 